\title{
HUBUNGAN ANTARA KONSUMSI EMPING MELINJO DENGAN KEJADIAN ASAM URAT PADA WARGA \\ DI DESA WADUNGGETAS WONOSARI KLATEN
}

\author{
Oleh : \\ Dinar Ariasti ${ }^{1}$, Wiji Lestari ${ }^{2}$
}

\begin{abstract}
Background:Uric acid is always present in the human body, when the rising levels (hyperuricemia) can cause complaints gouty arthritis. The cause of gout arthritis varies and is triggered by a diet high in purine. One diet high in purine include mlinjo (Gnetum gnemon linn) because it contains $50-150 \mathrm{mg}$ of purines per $100 \mathrm{~g}$ of beans melinjo, with one of the forms are processed emping melinjo. Results of preliminary observations most people are less concerned with what they eat everyday including emping melinjo consumed as a snack when relaxing. They did not know that eating emping could lead to an increased risk of gout.

The purpose of this study was to determine the relationship between the consumption of emping melinjo with the incidence of gout in Wonosari Wadunggetas residents in the village of Klaten.

The subjects were Wadunggetas Wonosari Klaten village residents over the age of 40 years a number of 30 respondents. The samples was conducted with a saturated sampling technique, namely by taking all members of the population being sampled because the population is small.

Methods in this study isanalytical research design correlation to determine the relationship of chips melinjo consumption as independent variables (independent variable) and the incidence of gout as the dependent variable (dependent variable). Data obtained by questionnaire and observation method. The data collected is then analyzed with chi square test with $\alpha 0.05$.

The results of the study there were 9 respondents with the level of consumption of chips often, all experienced gout, 14 respondents with a rare level of consumption of chips, 11 experienced gout and 3 are not experiencing gout and 7 respondents who do not eat emping no suffer from gout. After Chi-Square test with SPSS version 16.0 with $\alpha=5 \%(0: 05)$ so obtained $p 0.000 p$ value of $<0.05$, which means that $\mathrm{Ho}$ is rejected and $\mathrm{Ha}$ accepted.

The conclusion of this study is that there is a relationship between the level of consumption of emping melinjo with the incidence of gout in the village Wadunggetas Wonosari Klaten.
\end{abstract}

Keywords: Emping Mlinjo Comsumtion and Gout Disease

\section{PENDAHULUAN}

Sasaran terapi gout yaitu mempertahankan kadar asam urat dalam serum kurang dari $6 \mathrm{mg} / \mathrm{dL}$ dan nyeri yang diakibatkan oleh peningkatan serta penumpukan asam urat, pemberian terapi digunakan untuk mengurangi peradangan dan nyeri sendi yang ditimbulkan oleh penumpukan kristal monosodium urat monohidrat. Kristal tersebut ditemukan pada jaringan kartilago, subcutan dan jaringan particular, tendon, tulang serta ginjal. (Helmi, 2012) 
Berdasarkan data dari klinik gizi di Puskesmas Mandiraja 1 Kabupaten Banjarnegara Provinsi Jawa Tengah pada tahun 2011 didapat 55 pasien menderita asam urat dari 119 orang atau $27,6 \%$. Sedangkan pada bulan Januari sampai bulan April pada tahun 2012 didapat 42 dari 71 pasien menderita asam urat atau 59\%. (Asripa, 2011)

Peningkatan asam urat akibat dari gangguan metabolisme purin yang ditandai dengan hiperurisemia dan serangan sinovitis akut berulangulang. Kelainan ini berkaitan dengan penimbunan kristal urat monohidrat monosodium dan pada tahap yang lebih lanjut terjadi degenerasi tulang rawan sendi. Insiden yang dialami sebesar $1-2 \%$ terutama terjadi pada usia 30-40 tahun dan 20 kali lebih sering pada pria dari pada wanita. Penyakit ini terutama menyerang sendi tangan dan bagian metatarsofalangeal kaki. (Muttaqin, 2008)

Asam urat selalu ada dalam tubuh manusia, apabila kadarnya meningkat (hiperurisemia) dapat menimbulkan keluhan gout arthritis. Penyebab gout arthritis bervariasi dan dipicu oleh diet tinggi purin. Salah satu diet tinggi purin diantaranya mlinjo (Gnetum gnemon linn) karena mengandung 50-150 mg purin per 100 gr biji melinjo, dengan salah satu bentuk olahannya adalah emping melinjo. (Dewi, 2009)

Menurut informasi yang diperoleh dari Kepala Desa Wadunggetas Kabupaten Klaten didapatkan data di Desa Wadunggetas Kabupaten Klaten, masyarakat dewasa yang sudah mengalami asam urat tercatat sebanyak 20-30 orang pada tahun 2013 hingga tahun 2014, penyebab pasti dari masalah tersebut lebih banyak dijumpai karena makanan yang tidak sehat dan serta kurang aktivitas. Hasil observasi awal sebagian besar masyarakat kurang peduli dengan apa yang dimakan sehari-hari termasuk mengkonsumsi emping melinjo sebagai makanan ringan ketika bersantai maupun sebagai makanan pendamping nasi hal ini menjadi kebiasaan karena kebanyakan masyarakat memiliki pohon melinjo di pekarangan mereka, kemudian ketika panen biji mlinjo tersebut akan dibuat emping. Mereka tidak mengetahui bahwa makan emping bisa menyebabkan resiko peningkatan asam urat.

Berdasarkan latar belakang di atas, maka peneliti tertarik untuk melakukan penelitian dengan judul "Hubungan Antara Konsumsi Emping Melinjo dengan Kejadian Asam Urat pada Warga di Desa Wadunggetas Wonosari Klaten"

\section{TUJUAN PENELITIAN}

Untuk mengetahui hubungan antara konsumsi emping melinjo dengan kejadian asam urat pada warga di desa wadunggetas wonosari klaten.

\section{DESAIN PENELITIAN}

Penelitian ini merupakan penelitian analitik dengan desain korelasi untuk mengetahui hubungan konsumsi emping melinjo sebagai variabel bebas (independent variable) dan kejadian asam urat sebagai variabel terikat (dependent variable).

\section{POPULASI, SAMPEL DAN TEKNIK SAMPLING}

Menurut Sugiono (2004), sebagaimana yang dikutip oleh Hidayat (2009), Populasi adalah wilayah generalisasi yang terdiri atas obyek atau subyek yang mempunyai kuantitas dan karakteristik tertentu yang ditetapkan oleh peneliti untuk dipelajari dan kemudian ditarik kesimpulannya. Populasi pada penelitian ini adalah seluruh masyarakat Desa Wadunggetas Wonosari Klaten yang berusia lebih dari 40 tahun berjumlah 30 warga.

Sampel merupakan bagian populasi yang akan diteliti atau sebagian jumlah dari karakteristik yang dimiliki 
oleh populasi. Dalam penelitian keperawatan, kriteria sampel meliputi kriteria inklusi dan kriteria eksklusi, dimana kriteria tersebut menentukan dapat dan tidaknya sampel tersebut digunakan. (Hidayat, 2009)

Sampel pada penelitian ini adalah seluruh populasi yaitu masyarakat yang berusia lebih dari 40 tahun yang berjumlah 30 warga desa Wadunggetas Wonosari Klaten. Rentang umur ini dipilih karena beresiko terkena penyakit asam urat. Tehnik sampling merupakan suatu proses seleksi sampel yang digunakan dalam penelitian dari populasi yang ada, sehingga jumlah sampel akan mewakili seluruh populasi yang ada. Dalam penelitian ini peneliti menggunakan teknik sampling jenuh. Teknik sampling jenuh adalah pengambilan sampel dengan mengambil semua anggota populasi menjadi sampel. (Hidayat, 2009)

Pada penelitian ini sampel yang digunakan adalah seluruh warga yang mengalami keluhan asam urat di Desa Wadunggetas Wonosari Klaten.

Pada penelitian yang berjudul hubungan konsumsi emping melinjo dengan kejadian asam urat peneliti menggunakan alat ukur kuesioner dan checklist. Alat penelitian atau instrumen penelitian yang digunakan dalam penelitian adalah menggunakan lembar observasi untuk menilai tingkat konsumsi emping melinjo dengan 1 pertanyaan dan menilai kejadian asam urat 5 pertanyaan.

Metode pengumpulan data merupakan kegiatan penelitian untuk mengumpulkan data. Sebelum melakukan pengumpulan data, perlu dilihat alat ukur pengumpulan data agar dapat memperkuat hasil penelitian. Alat ukur pengumpulan data tersebut antara lain dapat berupa kuesioner atau angket, observasi, wawancara, atau gabungan dari ketiganya. (Hidayat, 2008)

Dalam penelitian ini pengumpulan data dilakukan dengan metode penyebaran lembar observasi dengan memberikan 1 pertanyaan kepada responden untuk mengetahui tingkat konsumsi emping melinjo dan 5 pertanyaan untuk mengukur angka kejadian asam urat karena konsumsi emping melinjo

\section{HASIL PENELITIAN}

Penelitian ini dilakukan mulai tanggal 20 Maret 2015 sampai dengan 20 April 2015 dengan jumlah responden sebanyak 30 orang. Tempat penelitian adalah Desa Wadunggetas kecamatan Wonosari Kabupaten Klaten. Di desa Wadunggetas terdapat banyak penderita asam urat berdasarkan hasil pemeriksaan lab di puskesmas. Di bawah ini akan dipaparkan hasil penelitian tentang hubungan antara konsumsi emping melinjo dengan kejadian asam urat di Desa Wadunggetas Wonosari Klaten.

Tabel 1. Distribusi Frekuensi Tingkat Konsumsi Emping Melinjo di Desa Wadunggetas Wonosari Klaten

\begin{tabular}{lcc}
\hline $\begin{array}{c}\text { Tingkat } \\
\text { Konsumsi }\end{array}$ & $\mathbf{f}$ & $\%$ \\
\hline Sering & 9 & 30 \\
\hline Jarang & 14 & 46,7 \\
\hline Tidak Pernah & 7 & 23,3 \\
\hline Jumlah & 30 & 100 \\
\hline
\end{tabular}

Dari tabel di atas ditemukan ada 9 responden $\quad(30 \%)$ yang mengkonsumsi emping dalam jumlah yang sering, 14 responden $(46,7 \%)$ mengkonsumsi emping dalam jumlah yang jarang, dan 7 responden $(23,3 \%)$ tidak pernah mengkonsumsi emping. Dapat dicermati bahwa konsumsi emping melinjo di Desa Wadunggetas sebagian besar pada tingkat sedang 
dan sering. Hal ini dikarenakan di desa Wadunggetas banyak terdapat pohon melinjo dan usaha olahan rumah tangga untuk emping melinjo sehingga mudah mendapatkan emping melinjo.

Tabel 2. Distribusi Frekuensi

Kejadian Asam Urat di Dusun Wadunggetas Wonosari Klaten

\begin{tabular}{ccc}
\hline $\begin{array}{c}\text { Kejadian } \\
\text { Asam Urat }\end{array}$ & f & $\%$ \\
\hline Ya & 20 & 66,7 \\
\hline Tidak & 10 & 33,3 \\
\hline Jumlah & 30 & 100 \\
\hline
\end{tabular}

Dari tabel di atas ditemukan 10 responden $(33,3 \%)$ tidak mengalami asam urat dan tidak menunjukkan tanda dan gejala penyakit asam urat dan 20 responden $(66,7 \%)$ mengalami penyakit asam urat berdasarkan hasil pemeriksaan lab dan tanda dan gejala yang dialami.

Dari hasil penelitian hubungan antara konsumsi emping melinjo dengan kejadian asam urat pada warga di Desa Wadunggetas Wonosari Klaten diperoleh hasil uji dengan Chi-Square program SPSS versi 16.0 dengan $\alpha=5 \%(0.05)$ diperoleh $p$ sebesar 0.000 sehingga nilai $p<0.05$, yang berarti Ho ditolak dan $\mathrm{Ha}$ diterima, sehingga dapat ditarik kesimpulan bahwa ada hubungan antara konsumsi emping melinjo dengan kejadian asam urat pada warga di Desa Wadunggetas Wonosari Klaten.

\section{PEMBAHASAN}

1. Tingkat Konsumsi Emping Melinjo Dari hasil tabel 1. dapat dicermati bahwa presentase pada kategori tingkat konsumsi emping paling banyak di Desa Wadunggetas adalah kategori jarang yaitu 14 responden $(46,7 \%)$ dan sering 9 responden $(30 \%)$ dari 30 responden. Mean (rata-rata) pada tingkat konsumsi emping melinjo sebanyak 3,97. Hal ini membuktikan bahwa tingkat konsumsi emping di Desa Wadunggetas pada tingkat sedang atau dalam sebulan hampir mengkonsumsi emping paling sedikit 3 kali dengan jumlah kurang lebih 100-150 gram. Dari wawancara dengan responden, mereka mengatakan bahwa di desa Wadunggetas terdapat banyak pohon emping melinjo dan warga banyak mengkonsumsi emping melinjo karena mudah didapat. Desa Wadunggetas juga terdapat produk rumahan emping melinjo sehingga warga mudah membeli emping melinjo. Oleh karena faktor kemudahan mendapatkan produk olahan emping melinjo, tingkat konsumsi emping melinjo di desa Wadunggetas cukup tinggi.

Tingkat pendidikan responden banyak berada pada tingkat SD yaitu sebesar 15 responden (50\%) dan tidak sekolah 6 responden (20\%). Tingkat pendidikan responden tersebut termasuk dalam tingkat pendidikan yang rendah. Tingkat pendidikan yang baik menurut Departemen Pendidikan adalah seseorang yang telah menempuh lama pendidikan minimal 9 tahun. Tingkat pendidikan yang baik akan mempengaruhi pengetahuan seseorang sebagaimana yang dikemukakan oleh Notoadmojo (2011), bahwa pendidikan seseorang mempengaruhi cara pandang atau masyarakat yang pendidikannya tinggi akan lebih mudah menerima informasi atau penyuluhan yang akan diberikan dan lebih cepat merubah sikapnya dalam kehidupan sehari-hari. Dalam penelitian ini ditemukan sebagian besar responden berpendidikan rendah yaitu tidak sekolah, lulusan SD 
dan SMP sejumlah 25 responden (83,3\%). Dari responden tersebut sebagian besar mengkonsumsi emping melinjo.

\section{Kejadian Asam Urat}

Hasil pengamatan kejadian asam urat di Desa Wadunggetas seperti yang tercantum dalam tabel 2 . terdapat 20 responden $(67,7 \%)$ menderita asam urat dari hasil observasi tanda dan gejala dan pemeriksaan asam urat dan 10 responden (33,3\%) tidak mengalami asam urat. Hal ini membuktikan bahwa penduduk Desa Wadunggetas banyak yang menderita asam urat. Dari pemeriksaan tanda dan gejala asam urat, sebagian besar responden mengeluhkan nyeri sendi, kaku, bengkak dan kemerahan pada persendian. Nyeri yang dirasakan responden terutama dirasakan pada malam hari. Seperti yang diungkapkan oleh Sudewo (2004), tanda dan gejala asam urat adalah rasa nyeri pada sendi, terutama pada ibu jari kaki atau sendi lainnya pada malam hari, kulit persendian yang terkena akan berwarna kemerahan, mengkilap, dan terasa sakit sekali ketika disentuh, adanya pembengkakan pada salah satu sendi dengan warna kemerahan dan disertai rasa yang sangat nyeri dan tidak sembuh dalam waktu 3 hari.

Dari pemeriksaan kadar asam urat banyak yang menunjukkan kadar asam urat diatas normal yaitu diatas $7 \mathrm{mg} / \mathrm{dl}$ untuk laki-laki dan lebih dari $6 \mathrm{mg} / \mathrm{dl}$ untuk perempuan. Hal ini seperti yang diungkapkan Saputra (2009), bahwa Hiperurisemia adalah peningkatan kadar asam urat dalam darah diatas normal yaitu kadar asam urat $>7 \mathrm{mg} / \mathrm{dl}$ pada laki-laki dan $>6 \mathrm{mg} / \mathrm{dl}$ pada perempuan. Hiperurisemia dan gout dibedakan menjadi hiperurisemia primer, sekunder dan idiopatik.

Dilihat dari karakteristik umur, semua responden berada pada umur lebih dari 40 tahun dan responden pria semuanya menderita asam urat. Seperti yang diungkapkan oleh Hendri (2008) sebagaimana yang dikutip oleh Dewi (2009), bahwa kadar asam urat darah dipengaruhi oleh herediter, jenis kelamin, kelainan enzim spesifik, idiopatik, faktor lingkungan, penyakit tertentu, kegiatan dan diet. Prevalensi hiperurisemia lebih banyak pada laki-laki dibandingkan pada perempuan, terutama pada lakilaki dengan usia di atas 40 tahun, sedangkan pada perempuan terutama saat menopause. Dalam penelitian ini jenis kelamin responden paling banyak adalah perempuan yang memasuki masa menopause yaitu 18 responden $(60 \%)$ dan sebagian besar menderita asam urat. Hal ini sesuai dengan apa yang diungkapkan Hendri di atas. Untuk faktor-faktor yang lain tidak dibahas secara mendalam dalam penelitian ini.

3. Hubungan Antara Konsumsi Emping Melinjo dengan Kejadian Asam Urat

Penelitian hubungan tingkat konsumsi emping melinjo dengan kejadian asam urat di Desa Wadunggetas Wonosari Klaten diperoleh hasil uji dengan ChiSquare program SPSS versi 16.0 dengan $\alpha=5 \%$ (0.05) diperoleh $p$ sebesar 0.000 sehingga nilai $p<0.05$, yang berarti Ho ditolak dan $\mathrm{H}_{\mathrm{a}}$ diterima, sehingga dapat ditarik kesimpulan bahwa ada hubungan antara tingkat konsumsi emping melinjo dengan kejadian asam urat di Desa Wadunggetas Wonosari Klaten. Menurut Siswono (2008) sebagaimana yang dikutip oleh 
Dewi (2009), diet merupakan salah satu faktor yang paling berperan dalam meningkatkan kadar asam urat. Beberapa contoh diet tersebut adalah daging merah, jeroan, makanan laut, melinjo, kacang-kacangan, sayuran dan bahan makanan lainnya. Salah satu diet yang paling dihindari oleh penderita hiperurisemia adalah melinjo, antara lain bentuk olahannya adalah emping. Konsumsi emping goreng berlebihan dikhawatirkan dapat meningkatkan kadar asam urat darah.

Menurut Damayanti (2012), makanan yang mengandung karbohidrat sederhana, protein dan purin yang tinggi seperti kacang-kacangan, emping dan melinjo akan merangsang peningkatan asam urat dalam tubuh sehingga akan menyebabkan pengkristalan pada persendian dan pembuluh kapiler darah terutama yang dekat dengan persendian. Penumpukan asam urat yang kronis menyebabkan cairan getah bening yang berfungsi sebagai pelumas (lubrikasi) sendi menjadi tidak berfungsi dan akibatnya persendian tidak dapat digerakkan.

Menurut Hariana (2008), emping melinjo mengandung tanin, saponin, dan flavonoid, polifenol, Kadar purin pada melinjo $366 \mathrm{mg}$ per 100 gram. Konsumsi makanan dengan purin tinggi seperti melinjo dapat meningkatkan kadar asam urat dalam darah serta minyak goreng yang digunakan untuk menggoreng emping hasil olahan melinjo tersebut juga dapat meningkatkan kadar asam urat.

Hasil penelitian ini juga sesuai dengan penelitian yang dilakukan oleh Dewi (2009) yang menyatakan bahwa asupan emping goreng dapat mempengaruhi kadar asam urat. Dengan hasil penelitian ini menggunakan analisis data uji "t" berpasangan dengan $\alpha=0.05$, dengan menggunakan program komputer. Dengan hasil rata-rata kadar asam urat sebelum konsumsi emping goreng adalah $4,9 \mathrm{mg} / \mathrm{dl}$ dan sesudah 3 jam pertama $5,3 \mathrm{mg} / \mathrm{dl}$, mengalami kenaikan secara signifikan $(p<0.01)$.

\section{KESIMPULAN}

Dari hasil penelitian hubungan tingkat konsumsi emping melinjo dengan kejadian asam urat di Desa Wadunggetas Wonosari Klaten diperoleh hasil uji dengan ChiSquare program SPSS versi 16.0 dengan $\alpha=5 \%(0.05)$ diperoleh $p$ sebesar 0.000 sehingga nilai $p<$ 0.05 , yang berarti $\mathrm{Ho}$ ditolak dan $\mathrm{H}_{\mathrm{a}}$ diterima, sehingga dapat ditarik kesimpulan bahwa ada hubungan antara tingkat konsumsi emping melinjo dengan kejadian asam urat di Desa Wadunggetas Wonosari Klaten.

\section{SARAN}

1. Bagi Dinas Kesehatan

Berdasarkan hasil penelitian terdapat hubungan antara tingkat konsumsi emping melinjo dengan kejadian asam urat. Diharapkan Dinas Kesehatan atau Puskesmas dapat memberikan penyuluhan tentang pencegahan penyakit asam urat terutama dari faktor pengaturan pola diet rendah purin.

\section{Bagi Responden Penelitian}

Diharapkan responden dapat meningkatkan pengetahuan tentang pencegahan terjadinya asam urat dengan mengikuti penyuluhan yang diadakan oleh dinas kesehatan atau puskesmas sehingga dapat mengatur pola diet rendah purin. 
3. Bagi Peneliti Selanjutnya

Tingkat pengetahuan konsumsi emping melinjo bukan satusatunya penyebab terjadinya asam urat, terdapat faktor konsumsi makanan yang lain yang dapat meningkatkan asam urat. Oleh karena itu diharapkan peneliti selanjutnya dapat melakukan penelitian tentang kejadian asam urat yang dihubungkan dengan faktor-faktor tersebut.

\section{DAFTAR PUSTAKA}

Ariani, Ayu Putri. Aplikasi Metodologi Penelitian Kebidanan dan Kesehatan Reproduksi. Yogakarta: Nuha Medika, 2014.

Bagus, ed. Solusi Sehat Mengatasi Asam Urat \& Rematik. Jakarta: AgroMedia Pustaka, 2009.

Damayanti, Deni. Panduan Lengkap Mencegah \& Mengobati Asam Urat. Yogyakarta: Araska, 2012.

Hariana, Arief. Tumbuhan Obat dan Khasiatnya Seri 2. Jakarta: Penebar Swadaya, 2008.

Helmi, Zairin Noor. Buku Ajar Gangguan Muskuloskeletal. Jakarta: Salemba Medika, 2012.

Hidayat, Aziz Alimul. Metode Penelitian Keperawatan dan Teknik Analisis Data. Jakarta: Salemba Medika, 2009.

.Riset Keperawatan dan Teknik Penulisan IImiah Edisi 2. Jakarta: Salemba Medika, 2008.

Muttaqin, Arif. Buku Ajar Asuhan Keperawatan Klien Gangguan Sistem Muskuloskeletal. Jakarta: EGC, 2008.
Puspitasari, Ika. Jadi Dokter untuk Diri Sendiri. Yogyakarta: B First, 2010.

Saputra L. Gagal Ginjal Kronik, Dalam : Intisari IImu Penyakit Dalam. Tangerang: Binarupa Aksara. 2009.

Sudewo, Bambang. Tanaman Obat Populer Penggempur Aneka Penyaki. Jakarta: AgroMedia Pustaka, 2004.

Suparni, Ibunda dan Ari Wulandari. Herbal Nusantara:1001 Ramuan Tradisional Asli Indonesia. Yogyakarta: Rapha Publishing, 2012.

Asripa, Rina. Faktor-faktor Yang Mempengaruhi Kepatuhan Diet Pada Penderita Asam Urat Di Puskesmas Mandiraja 1 Kabupaten Banjarnegara Jawa Tengah. 2011. Diakses tanggal 30 November 2014.

Dewi, Ni Luh Putu Ayu. Efek Asupan Emping Goreng (Produk Olahan Melinjo "Gnetum Gnemon") Terhadap Kadar Asam Urat Darah Laki-Laki Dewasa. 2009. Diakses tanggal 30 November 2014.

Wijayanti, Rahayu. Faktor Yang Mempengaruhi Terjadinya Penyakit Artritis Gout. 2008. Diakses tanggal 30 November 2014.

\footnotetext{
1 Dosen AKPER Panti Kosala Surakarta

2 Mahasiswa AKPER Panti Kosala Surakarta
} 